\title{
Hydraulic conductivity of compacted granite residual soil mixed with Palm Oil Fuel Ash in landfill application
}

\begin{abstract}
Laboratory tests were carried out on compacted granite residual soil treated with 0 to $15 \%$ Palm Oil Fuel Ash (POFA), with a view to evaluate its hydraulic conductivity for its application in landfilling. The Soil-POFA mixtures were compacted using both Standard and Modified Proctors compactive efforts at $2 \%$ dry of Optimum Moulding water Content $(-2 \%)$, at Optimum Moulding water Content $(0 \%)$, at 2 and $4 \%$ on the wet side of Optimum Moulding water Content $(+2$ and $+4 \%)$. The samples were permeated with water and the effect of moulding water content; compactive effort and POFA content were examined. The samples that met the minimum threshold of $1 \times 10^{-9} \mathrm{~m} / \mathrm{s}$ were used in plotting the acceptable zones criterion at various POFA mixtures. The results gave indications of reduction in the hydraulic conductivity values, with increase in compactive efforts, moulding water content and POFA content up to about $10 \%$. This was the most suitable soil-POFA mixture for the hydraulic application.
\end{abstract}

Keyword: Hydraulic conductivity; Palm Oil Fuel Ash; Granite residual soil; Landfill 